\title{
Chapter 23 \\ Proposals for Reforms and Democratization of the EMU
}

\author{
Bettina De Souza Guilherme
}

\begin{abstract}
In this part of the book, we discuss proposals to improve architectural and crisis management lacunas. While other partners of the network present own proposals, this chapter has the objective to sketch out proposals, which have been discussed or are still in the pipeline at the top level of European Union (EU) decision-takers and institutions to remedy lacunas, errors and omissions of the Economic and Monetary Union (EMU) architecture. A main argument advanced is that the reforms with a focus on "risk-avoidance" and stronger "surveillance" and "monitoring" had more success, while any reforms based on the principle of "risksharing have encountered major resistance, both for the financial market regulation and for the fiscal framework.
\end{abstract}

\section{EMU Design Flaws and Ongoing Reforms}

Design flaws of the Economic and Monetary Union (EMU) have been extensively discussed in the first part of the joint volume. EMU's imbalances and instability have their origin within its asymmetric construction both in terms of a fully fletched supranational monetary union and a largely intergovernmental fiscal policy coordination and in terms of risk avoidance and risk-sharing mechanisms. The focus of the surveillance before the crisis was on the fiscal deficits, while both public and private debt, and the rise and risks of macroeconomic imbalances and of deregulated financial markets were largely disregarded. EMU did not have the institutions, finances, tools and rules in place to deal with the crisis in an efficient, adequate and equitable way. Informal bodies outside of the EU legal framework rose to be the top decisionmaking institutions taking decision with major impact on the lives and work of EU citizens, while democratic accountability was eroded both at EU and at national levels.

\footnotetext{
B. De Souza Guilherme ( $\square)$

Founder and Co-coordinator of the Jean Monnet Network "Crisis-Equity-Democracy for Europe and Latin America”, IRELAC, Rio de Janeiro, Brazil

European Parliament, Brussels, Belgium

e-mail: bettina.desouza@europarl.europa.eu
} 
The reform of the financial market regulation has advanced considerably in the aftermath of the Lehmann's bank default, leading to the establishment of the "Banking Union," with a strengthening of financial service regulation and the introduction a supranational supervision by the European Central Bank for systemically relevant banks as the first pillar. This can be considered a major achievement, which prior to the crisis would have been difficult to envisage. The second pillar of the Banking Union deals with a single resolution mechanism (SRM), regulating the orderly restructuring of a bank by a resolution authority when the bank is failing or at risk to fail for the banks covered by the single supervisory mechanism to avoid that tax payers have to pay once again for a failing bank sector. This is why it has at its heart the Single Resolution Fund (SRF), financed by contributions of the banking sector. In case that the SRF does not have sufficient means, the Member States decided in 2013 the establishment of a "common backstop," which would serve as a safety net in case that, after a bailing in or haircut of the banks' shareholders and creditors, the Single Resolution Fund would temporarily not have sufficient resources for an orderly resolution of the distressed banks. The Commission proposed to make the backstop part of a future European Monetary Fund (EMF), to be established within the EU legal framework, but the Eurogroup preferred to keep the intergovernmental European Stability Mechanism (ESM) in place and decided in December 2019 to establish the common backstop in the ESM at the latest by 1 January 2024. "The size of the credit line(s) will be aligned with the target level of the SRF, which is $1 \%$ of covered deposits in the Banking Union (currently estimated at around $€ 55$ billion). If the credit line is used, the SRF will pay back the ESM loan with money from bank contributions within three years, although this period can be extended by up to another two years. As a result, it will be fiscally neutral over the medium term."

In terms of increasing financial stability and the resilience of EMU, the common backstop represents indeed a major step forward and a precious contribution. In terms of democratic accountability on the other hand, the fact that the ESM was entrusted with the common backstop could eventually signify the perpetuation or at least the prolongation for a considerable time of an intergovernmental crisis management void of proper democratic accountability. A solution could be to transform the ESM into the EMF through co-decision, however duly allowing the European Parliament to make an input in the shaping of this important crisis management tool after all the failures and policy errors in the crisis management and, second, to ensure its accountability.

However, it is clear that even given the common backstop, the missing part of the regulation and improved resilience as part of the consolidation of the crisis management in the financial markets sector is the risk-sharing element, the third pillar of the Banking Union, which is the European Deposit Insurance Scheme (EDIS). In November 2015, the Commission presented a proposal on the European deposit

\footnotetext{
${ }^{1}$ Explainer on ESM reform and revisions to the ESM Treaty, ESM website: https://www.esm. europa.eu/about-esm/esm-treaty-reform-explainer. Accessed 01 March 2020.
} 
insurance scheme (EDIS) for bank deposits in the euro area, building on the system of national deposit guarantee schemes, which guarantees the deposit of up to 100,000 euros in the case that a bank fails in all EU member states and is funded entirely by banks. EDIS would provide a stronger and more uniform degree of insurance cover in the entire euro area and thus provide a strong protection against speculation. The Commission proposal foresees a gradual introduction of EDIS with first a "reinsurance phase" in which EDIS would provide liquidity to national Deposit Guarantee Schemes (DGS) in case of a bank failure, which would then have to be paid back by the national DGS. In a later phase, the principle of "coinsurance" would apply and EDIS could also cover losses, without that national DGS would repay them (European Commission 2020). EDIS would on the one hand reduce the vulnerability of national DGS with limited financial means to large local shocks and on the other hand move against the sovereign-bank nexus by significantly reducing the link between banks and their national sovereign ensuring that the level of depositor confidence in a bank would not depend on the bank's location. This could signify an important stepping stone in the direction of a genuine European financial and capital market. However, negotiations were blocked by both the European Parliament and even more in the Council, until late 2019, when the German finance minister Scholz presented a proposal on EDIS. However, his proposal restricts EDIS to the reinsurance phase and request at the same time more stringent conditions such as a concrete target for nonperforming loans (NPLs). According to the IMF's Compilation Guide on Financial Soundness Indicators 2004 "a loan is nonperforming when payments of interest and/or principal are past due by 90 days or more, or interest payments equal to 90 days or more have been capitalized, refinanced, or delayed by agreement, or payments are less than 90 days overdue, but there are other good reasons5 - such as a debtor filing for bankruptcy-to doubt that payments will be made in full. After a loan is classified as nonperforming, it (and/or any replacement loans(s)) should remain classified as such until written off or payments of interest and/or principal are received on this or subsequent loans that replace the original." Scholz's proposal envisages a NPL ratio of below 5\% gross and $2.5 \%$ net, country by country and to introduce non-zero credit risk weights and a concentration charge on government debt which would increase capital cost for large exposures to individual countries. Both conditions are detrimental to highdebt countries like Italy, Portugal and Greece, and the most recent German proposal might fail for this reason. The German proposal is a clear attempt to transform a proposal, which was meant to be the strongest risk-sharing element of the Banking Union, into another element of risk reduction and at the same time falls short of the aim of EDIS to give to same feeling of security to avoid a bank run or the distinction of the rating of the security of deposits according to the location of the deposit.

Risk avoidance had already been the main characteristic of the Maastricht original design of the fiscal framework. Following the crisis, it was further strengthened with the 2 and 6 packs, the Fiscal Compact, the institutionalization of the so-called European semester, which is the coordination process of economic policies, the establishment of the Macroeconomic Imbalance Procedure (MIP) to monitor any developments which could lead to new imbalances. At the same time, the crisis 
management and the reforms widened the democratic deficit brought about by the increase of intergovernmentalism with the rise of the informal Eurogroup together with the Eurosummit to the most important decision-taking bodies of the EMU, and the creation of further intergovernmental institutions such as the ESM and intergovernmental treaties such as the Fiscal Compact, all outside of the legal framework of the EU and bypassing the democratic accountability of the European Parliament and in many cases of national parliaments. These developments have induced a process of erosion of democratic legitimacy and accountability both at national and at EU levels and successively led to a loss of trust in traditional political institutions at EU level but even to a stronger extent at national level with the rise of protest movements, mushrooming of new parties and movements, an increasing polarization of society and politics. Neither of the previously mentioned democratic erosions has so far been remedied.

First, the asymmetric construction of EMU hampered its resilience and proved ineffective to avoid or shield from a crisis, and the reforms in the aftermath of the crisis have at best shown mixed results. The further tightened fiscal rules showed success in imposing discipline in regard to the fiscal deficits, which led to a slow reduction of the public debt level towards the pre-crisis level over a timespan of more than 10 years (however not yet reached). On the other hand, the fiscal framework, even more with the reforms and the imposed adjustment programmes, proved to be largely pro-cyclical, inefficient to protect the quality of public expenditure-in other words growth-enhancing investment-with negative impacts on productivity, competitivity and growth, and inefficient to lead to a reduction of the debt level of highly indebted countries, as has been reported by the president of the European Fiscal Board (EFB) to the European Parliament (European Fiscal Board 2019). The European Fiscal Board, an independent advisory body to the European Commission with the objective to improve the current economic governance framework of the Economic and Monetary Union, criticized the multiple sources of unnecessary complexity in the current framework and proposed its simplification with a focus rather on debt reduction than on the public deficit. The EFB proposals rely on "a simple medium-term debt ceiling and one operational target, namely, a ceiling on the growth rate of primary expenditure net of discretionary revenue measures, and an escape clause triggered on the basis of independent economic judgement. This proposal would focus more clearly on underpinning sustainability, improve observability, simplify the rules and reduce pro-cyclicality." Additionally, the European Fiscal Board proposes the introduction of a limited Golden rule to protect public investment. The EFB proposes to exclude some "specific growth enhancing expenditure from the net primary expenditure growth ceiling" and "national fiscal council institutions could monitor the classification of growth-enhancing expenditure" (European Fiscal Board 2019).

In the meantime, climate change had proven to be a major threat to human survival and requires a change of paradigm which will affect all fields of policy, including economic and financial policies. The last elections to the European Parliament increased both its legitimacy and the pressure to address the climate crisis with serious action. As a consequence, the newly invigorated European Commission 
adopted the European Green Deal as part of which the Commission announced that it will refocus the European Semester process of macroeconomic coordination to integrate the United Nations' Sustainable Development (SDGs) goals, to put sustainability and the well-being of citizens at the centre of economic policy, and the sustainable development goals at the heart of the EU's policymaking and action. With the refocusing of the European Semester, the Commission changed the Annual Growth Survey into the Annual Sustainable Growth Strategy 2020 and with it the content: "Environmental sustainability, productivity gains, fairness and macroeconomic stability will be the four dimensions of our economic policy in the years to come. These dimensions, which are closely interrelated and mutually reinforcing, should guide structural reforms, investments and responsible fiscal policies across all Member States" (European Commission 2019, p. 3).

The Climate Change Agenda goes beyond fiscal policies, and the Council and European Parliament negotiated a list of investment (taxonomy) which should serve as guidelines for the ECB, EIB and financial markets, which investments should be considered environmentally friendly and should be favoured. With the coinciding of the Climate Change Agenda and outstanding reforms of the fiscal framework, the coming years will be decisive for implementing reforms which will render the EU more resilient for financial, economic and climate crisis. However, one cannot close the eyes to the fact that there is a lot of resistance to changes and efforts to water down or limit reforms as was the case with the Financial Transaction Tax (FTT) to make the financial markets pay taxes in general (as any other business sector) and compensate for the enormous costs the financial crisis had caused but also taking into account the resistance against a common fiscal capacity to counteract against asymmetric shocks. Indeed, the crisis gave rise to various concepts of fiscal capacities which remained not only at the academic level but entered the deliberation at the highest level of the EU institutions.

The European Parliament was indeed the first EU institution, which in 2011, after a nearly 2 years of extensive hearings with experts, fact finding missions and deliberation-within its Special Committee on the Financial, Economic and Social Crisis-founded with the purpose to evaluate the causes and make proposal for a better crisis resilience of EMU, voted in favour of a euro-area budget and of "the development of the concept of a European Treasury to strengthen the economic pillar of EMU." (European Parliament 2011) According to the European Parliament, the euro-area budget should be "a budget of sufficient size to accommodate the euro in a sustainable way, providing the currency with a relevant budget space on the level of political organisation at which it is issued." Concerning the details on a euro-area budget, the European Parliament referred in its resolution to the McDougall report (European Commission 1977), which had analysed the conditions necessary for the implementation of the Werner plan for an Economic and Monetary Union in the 1970s and affirmed that: (1) the volume of such a budget would have to be between 2,5 and 10 percent of Union GNI, depending on whether and which reallocation functions would be assumed by the Union budget (...); (2) the budget would need to be financed on the basis of own resources, (...) and; (3) national 
budgets would be reduced correspondingly in order to achieve tax neutrality for citizens and businesses.

The president of the European Council together with the Presidents of the Commission, the Euro-group and the European Central Bank published the "Four Presidents Report" (Van Rompuy 2012), which underlined that "while the degree of centralization of budgetary instruments and the arrangements for fiscal solidarity against adverse shocks differ, all other currency unions are endowed with a central fiscal capacity." The report defines a specific and time-bound road map for the achievement of a genuine Economic and Monetary Union with the objective to improve the resilience of EMU. The Four Presidents envisaged "the creation of a shock-absorption function at the central level," as the "culmination of the process" of achieving a fully fledged EMU in its stage 3 (post 2014). In their report, they stress that the establishment of "a well-defined and limited fiscal capacity to improve the absorption of country specific economic shocks, through an insurance system set up at the central level" accompanied by "a built-in incentives-based system (which) would encourage euro area Member States eligible for participation in the shock absorption function to continue to pursue sound fiscal and structural policies in accordance with their contractual obligations."

The envisaged proposal should thus link "the two objectives of asymmetric shock absorption and the promotion of sound economic policies" with the intention to render them "complementary and mutually reinforcing." Additionally, it emphasizes the importance of an "increasing degree of common decision-making on national budgets and an enhanced coordination of economic policies," in particular in the field of taxation and employment, to prepare for this stage.

The European Commission published its Reflection Paper on Deepening the EMU in May 2017 and announced that it will look into different options for a macroeconomic stabilization function for the euro area such as: (1) a European Investment Protection Scheme; (2) a European Unemployment Reinsurance Scheme; (3) a rainy day fund that could accumulate funds on a regular basis; (4) a dedicated euro-area budget; (5) the conversion of the ESM into a European Monetary Fund integrated in the EU legal framework.

In addition to these stabilization facilities, the Commission announced an instrument or budget line to support (administrative) capacity building and/or structural reforms, which should also support convergence and cohesion to counteract internal imbalances, and proposed a regulation establishing the Structural Reform Support Programme. An interesting feature of the Reform Support Programmes as well as of the Commission Proposals on the Common Provision Regulation (CPR) for all the Structural and Cohesion funds is the idea to rather work with incentives to better implement the Country-Specific Recommendations (CSR) of the European Semester as a conditionality. This approach should be the carrot to incentivize adherence to the Country-Specific Recommendations (CSR) of the European Semester additionally to the enhanced surveillance of the European Commission with the possibility of sanctions, which represents the whip.

In 2018, the Commission presented its proposal on the establishment of a European Investment Stabilization Function (EISF) building on the Five Presidents' 
report (Juncker 2015) and on the Commission Reflection Papers on Deepening the EMU and on the future of EU finances of 28 June 2017. The proposal has the objective to protect investment in the event of a downturn, by supporting well-identified priorities and already planned projects or activities at national level, such as infrastructure or skills development. As experienced in the Great Recession, public investment was the first to be cut in the national budget, which actually deepened the economic crisis and had detrimental effects on growth, employment and productivity. The proposal is based on Article 175(3) of Treaty on the Functioning of the European Union (TFEU), which allows for the creation of an instrument supporting eligible public investment in Member States that are confronted with a large asymmetric shock with a view to strengthen cohesion. It would empower the Commission to grant financial assistance to Member States, which are faced with a large asymmetric shock, by contracting borrowings on the financial markets or with financial actors and lending them on to the Member State concerned to maintain eligible public investment, specified in an Annex. Additionally, the proposal included the possibility that the interest rate costs incurred on the loan could be subsidized. With the purpose to link both the risk reduction and risk-sharing approach, access to the Stabilization function is conditional on compliance with decisions and recommendations under the fiscal and macroeconomic surveillance framework.

The criterion to activate the support is a double unemployment trigger, because strong increases in national unemployment rates are a relevant indicator of the impact of a large asymmetric shock. Additionally, it includes an obligation to use the support received for investment in policy objectives under the Common Provisions Regulation and to maintain the average level of public investment of the last 5 years. The proposal was both long awaited but also encountered strong criticism on the one hand from those who are in principle against any risk sharing and on the other hand for the rather modest volume of $€ 30$ billion earmarked for it.

The European Parliament (2015) having already expressed its support for a fiscal capacity, and stabilization function took up the challenge to deliberate on the bases of the draft report of the co-rapporteurs Beres-Boege within a joint committee of Budget and ECON members among the following lines: First of all, the report proposes that activation trigger should be "automatic," still based on both the level of national unemployment rate compared to its past average and the change in unemployment compared to a certain threshold. The rapporteurs intended to avoid delays for the activation and the repetition of the previously witnessed political conflicts around financial assistance. Furthermore, with the intention to avoid any revival of debtor and creditor conflicts on the financial means, the European Parliament's draft report additionally proposed to feed the fund with Member States' contributions of $10 \%$ of monetary income allocated to the national central banks of the Eurosystem pursuant to Article 32 of Protocol No 4 on the Statute of the European System of Central Banks and the European Central Bank ${ }^{1 a}$ and that it should not be less than billion euros. In this way, the Parliament intended to increase the budget for the EISF to at least $€ 55$ billion. Additionally, to the conditionality proposed by the Commission, the EP asked for compliance with "a convergence code" focusing on a few decisive criteria allowing for better national ownership and for a special clause 
ensuring that EISF support should be conditional on respect for Union values, and Member States subject to a procedure pursuant to Article 7(1) or (2) of the Treaty on the European Union should not be eligible.

The Parliament (2017) preferred the EISF to be independent from, and in parallel to the ESM and his successor and to ensure a much greater accountability than the non-existing accountability of an institution founded outside of the EU legal framework with a yearly exchange of view with the relevant committee and immediately, whenever the EISF becomes operational. However, given that the report fell into the last year of the legislature, it became victim to the increased political polarization in the European Parliament ahead of elections and was not put to vote. It remains a pending file to be picked up once one of the future presidencies, possibly the Portuguese, in the first half of 2021, intends to push for it again.

In the Council, the proposal had encountered major resistance and did not advance much. Indeed, the proposal can also be seen as a fruit of the strong push for a Eurozone budget by the newly elected French president Emanuel Macron. In his speech of 26 September 2017 at the University of Sorbonne, the newly elected president presented his clearly pro-European stance and highlighted the importance of a euro-area budget to provide public goods and stability when confronted with economic shocks: "We need convergence and stability through national reforms, but also by coordinating our economic policies and a common budget. If we want to reduce our differences and develop our common goods - everything I have just mentioned, security, protection in the context of migration, digital transition, ecological transition, a genuine development and partnership policy - these common goods, foremost among which is our currency, must be financed. And we therefore need more investment, we need the means to provide stability in the face of economic shocks, as no state can tackle an economic crisis alone when it no longer controls its monetary policy. So for all these reasons, yes we need a stronger budget within Europe, at the heart of the eurozone."

To achieve a euro-area budget, the German support is essential, and in June 2018, Macron achieved an agreement with Merkel, which was a compromise and spelled out in the Meseberg Declaration, in which they proposed "establishing a Eurozone budget within the framework of the European Union to promote competitiveness, convergence and stabilization in the euro area, starting in 2021. Decisions on the funding should take into account the negotiations on the next Multiannual financial framework. Resources would come from both national contributions, allocation of tax revenues and European resources" (Macron and Merkel 2018). However, in the text, it no longer defined the purpose of the eurozone budget to be for stabilization but rather to increase "competitiveness and convergence, which would be delivered through investment in innovation and human capital. It could finance new investments and come in substitution of national spending." Instead of the European Investment Stabilization Function, the Meseberg Declaration proposed a European Unemployment Stabilization Fund, for the purpose of stabilization in case of severe economic crises, without transfers. This idea was promoted by the German Finance Minister Olaf Scholz, but found strong opposition both within the German parliament and among the Nordic countries of the European Union. 
The Unemployment Re-Insurance Scheme has the aim to provide countercyclical stabilization in case of large labour market shocks and could be funded by national contributions and then grant loans to national unemployment insurance schemes in times of severe economic crises. The objective of the loans would be to avoid cuts in unemployment benefits or increases in social insurance contributions in recessions and thereby would allow the role of domestic unemployment insurance schemes to act as an automatic stabilizer (which had been restrained by the adjustment programmes). Additionally, it would help to support income in a recession or stagnation and in particularly the social strata which bears a large part of the social costs in a recession, which in term would increase the trust in European institutions (Beblavý et al. 2015). According to an impact assessment by the Bertelsmann Foundation (Dolls 2018), the re-insurance scheme would have cushioned on average $15-25 \%$ of the income losses following large labour market shocks in the period 2000-2016 through the interregional smoothing channel of the re-insurance and would have been revenue-neutral at EA19 and not led to permanent transfers across member states. On average, the member states would have paid less than $0.1 \%$ of their gross domestic product (GDP) annually.

Some of the proposals of the European Commission's Reflection Paper go beyond a funding mechanism and don't have the target to mitigate economic shocks. While the newly elected Commission president, Ursula Von der Leyen, announced a proposal for a European Unemployment Reinsurance Scheme to be presented by the end of 2020, the only proposal following up Macron's call for a euro-area budget, which is currently being negotiated in the Council and the European Parliament, is the budgetary instrument for convergence and competitiveness for the euro area (BICC). It is a new version of the Reform Support Programme+. In practice, it extends the programme from its previous focus on structural reforms to investment relevant for convergence and competitiveness. It will not fulfil the purpose of a stabilization of the eurozone in asymmetric shocks, but, if designed in an appropriate way, it could help to improve the competitiveness and the convergence of the weaker regions and countries and thus counteract the internal imbalances. However, given the strong conditionality to the adherence to the fiscal framework and the countryspecific recommendations, some of the peripheral countries fear that it will rather lead to a kind of "rebate" because the countries which are meeting these preconditions might in fact be the strongest economies.

One of the objectives is to offer a carrot to a greater adherence to the countryspecific recommendations within the European semester. However, the budget foreseen in it is also limited to $€ 30$ billion, which raises the same criticism as the proposal of the EISF and the reform support programme. The former ECB president M. Draghi considered the agreement on "the Budgetary Instrument for Convergence and Competitiveness a step in the right direction, but it does not yet meet the necessary criteria in terms of size or design." According to him, "The most effective response, however, would be an investment-led stimulus at the euro area level. This would be the best way to achieve an efficient distribution of spending among euro area countries - and is a further reason why I have called for a euro area fiscal instrument." 
Another instrument which has better chances to be achieved because it tries to avoid any mutualization of debts or permanent transfer is the idea of the Rainy Day Fund. A rainy day fund has however the handicap that it would normally limit its payments to the accumulated contributions and would probably be too small in case of a large shock. Lenarčič and Korhonen (2018) published a saving-loans proposal of the Rainy Day Fund (RDF), which would avoid (permanent) transfers between member-states in the form of a "non-mutualised European RDF, composed of national compartments. In good times, countries would accumulate savings in their compartments, accruing self-insurance. In bad times, they would be entitled to use the savings in their own compartment, and - if needed - could access limited borrowing from the rest of the fund. Further, the rules for national contributions, payouts, and repayment of any loans would be based on changes in unemployment rates, rather than on levels," and would "follow the Carnot et al. (2017) 'double condition' rule which assumes payments to the fund when unemployment is low and decreasing and disbursements when it is high and increasing. Countries would repay their loans according to rules similar to those for fund contributions, while observing a final maturity linked to the average length of the business cycle" (Lenarčič and Korhonen 2018).

In addition to the Euro-area budget and treasury, the European Parliament had already in 2011 supported the possible mutual issuance of sovereign debt, Eurobonds stimulating fiscal discipline and the EU's borrowing capacity. The European Parliament's concept on the Eurobonds was largely based on a proposal by Delpla and Von Weizsaecker (2011) on the blue bond (2010) and foresaw "that when Eurobonds are to be issued, their issuance should be limited to a debt ratio of $60 \%$ of GDP under joint and several liability as senior sovereign debt, and should be linked to incentives to reduce sovereign debt to that level" and that "the overarching aim of Eurobonds should be to reduce sovereign debt and to avoid moral hazard and prevent speculation against the euro." At the same time "access to such Eurobonds would require agreement on, and implementation of, measurable programmes of debt reduction."

The appealing feature of the Delpla and Von Weizsaecker proposal was that the blue bonds would constitute "a liquid and safe asset on par with the US Treasury bond. This should help the rise of the euro as a major reserve currency, enabling the entire euro area to borrow part of the sovereign debt at interest rates comparable to, or hopefully even below, the benchmark German bond" (Delpha and Von Weizsaecker 2011). Von Weizsaecker continued his commitment to the Eurobonds as a member and rapporteur on the subject "Sovereign bond-backed securities (SBBS)" in the European Parliament. The creation of European Safe Bonds (ESBies) should help to resolve the 'diabolic loop' between sovereign and bank risk, coupled with cross-border 'flight-to-safety' capital flows by serving as securities issued by a European Debt Agency (EDA)." ESBies should be composed of the senior tranche on a portfolio of sovereign bonds issued by EU Member States, held by a European Debt Agency or the ESM and potentially further guaranteed through a credit enhancement. The European Commission's legislative proposal foresaw that the SBBS would consist of a diversified pool of euro-area sovereign bonds, 
according to their economic weight. Advantages of the SBBS are that they would be considered save and not require any form of fiscal solidarity among euro-area governments.

Concerning a possible European Debt Agency, the European Parliament had already in 2011 requested to transform the temporary European Financial Stability Fund (EFSF) into a European Debt Agency and the Parliament to be given a consistent role in this modification of the Treaty. However, the European Parliament had no say in the establishment of the European Stability Mechanism (ESM), whose objective is to provide financial assistance to the euro-area Member States, which undergo a balance of payment crisis, which risks to endanger the financial stability of the euro area or of its MS. The EMS remained up to this day a purely intergovernmental organization outside of the legal framework of the EU, which has been condemned by the European Parliament as a "setback in the development of the Union, essentially at the expense of Parliament, the Court of Auditors and the Court of Justice."

During the Euro crisis, the Eurogroup set up the co-called "Troika," consisting of the European Commission (DG Ecfin), the European Central Bank and the International Monetary Fund (IMF) to set up the adjustment programmes for the debtor countries and to monitor their implementation. Since the Eurogroup is not a formal institution within the EU legal framework, the entire set-up of the financial assistance was exposing a blatant void of democratic legitimacy and accountability. EU institutions were "instrumentalized" to implement and monitor the political guidelines decided within the Eurogroup in "consensus." Given that no procedures and rules for any case of "risk of sovereign default" had been foreseen, the debtor countries were absolutely dependent on the "good" or "bad" will of the creditor countries, which resulted that the costs of the adjustment of the internal imbalances and the bailing out of financial institutions (mainly from the creditor countries) fell entirely on the debt countries. It is obvious that the set-up of the decision-making process resulted in a number of conflicts of interest of this crisis management process given the involvement of their national banks in the creditor countries. The European Parliament established the so-called Troika Inquiry Committee to analyse how these financial assistances had been handled. It exposed further conflict of interest of the European Central Bank - being responsible for the supervision of the biggest financial institutions and its role as the central bank (and normally lender of last resort) of all EU Member States, which lead the ECB to prevent the bailing in of the banks-at least in the first years of the crisis and thus insisting in rolling over the costs of the bank failures to citizens and tax payers. At the same time, it seems contradictory that an "independent" central bank imposes on Member States to change their traditional, equally "autonomous" collective bargaining structures by social partner to the detriment of labour. The current irony of history is that the ECB is not able to fulfil its primary objective to maintain price stability with the aim at inflation rates of below, but close to, $2 \%$ over the medium term. The inflation rate for 2019 has been 1.3\%, and one of the main reasons is that in spite of the improved employment situation wage growth does not pick up given wage bargaining shocks and the increased number of involuntary part-time, both a consequence of structural 
reforms as recommended or imposed. The European Commission was as well acting in obvious conflict of interest as it is the institution which should be the guardian of the EU treaties, including the Charter of Fundamental Rights and all the objectives of Europe 2020.

Some might argue that the imposed austerity programmes were a necessary evil to lead the crisis countries to a situation of sound public finance and to calm the financial markets. However, in retrospect, it is clear that the policy recommendations had not sufficiently taken into account the criteria of debt sustainability at the beginning of the financial assistance (as is usually a precondition of the involvement of the IMF), had been based on overoptimistic forecasts which were unrealistic to achieve, had ignored the functioning of fiscal multipliers and thus led-as had been admitted both by the IMF and the Commission-to a largely pro-cyclical policies which deepened and prolonged the crisis and finally even led to an increase of the debts of the debtor countries. Here I would like to introduce a crucial question: Would anybody in retrospect consider these policy recommendations in such an economic situation and within the given fiscal framework of the EMU as "sound budgetary policies" and will they be the same policies again? Were the underlying reasons behind these draconian but economically nonsensical measures at the given time not rather meant as a deterrent for any future fiscal lenience? Indeed, this is the Achilles heel of any future assistance programme design. ECB's Draghi resumed in his farewell remarks that "in other regions where fiscal policy has played a greater role since the crisis, we have seen that the recovery began sooner and the return to price stability has been faster. The US had a deficit of $3.6 \%$ on average from 2009 to 2018 , while the euro area had a surplus of $0.5 \%$. In other words, the US has had both a capital markets union and a counter-cyclical fiscal policy. The euro area had no capital markets union and a pro-cyclical fiscal policy." However, his quotation exposes the fact that according to the standards of the EU fiscal framework, the surplus of $0.5 \%$ would certainly be considered the sounder budgetary policy and would be reapplied again. It might be worthwhile to empower the European Fiscal Board to have a role in the definition of the adjustment programmes, as recommended by Christian Ghymers (Chap. 22), however, after the European Parliament has defined a framework of (human) and social rights, which must not be undermined again.

The European Court of Justice has clearly explained the conditions for financial assistance in the EU: Article 125 TFEU does not prohibit the granting of financial assistance by one or more Member States to a Member State which remains responsible for its commitments to its creditors provided that the conditions attached to such assistance are such as to prompt that Member State to implement a sound budgetary policy. Based on this article, the ESM financial assistance is strictly conditional on the implementation of policy measures. As previously with the Troika, measures are specified in a Memorandum of Understanding (MoU), but will be negotiated by the European Commission on behalf of the ESM, the European Central Bank (ECB), the International Monetary Fund (IMF) (where applicable) and the beneficiary Member State. The lending instrument and the attached conditions are approved by the ESM Board of Governors, which is composed of the Euro 
Area Finance Ministers. In other words, the ESM is once again the prolonged arm of the Eurogroup, instrumentalizing both the European Commission and the ECB for the purpose of elaborating Memorandum of Understandings in line with their guidelines, by taking decisions in consensus, risking to repeat the same kind of conflicts as experienced in the past crisis. Additionally, although both institutions participate regularly in exchange of views in the European Parliament, neither the Eurogroup nor the ESM is legally democratically accountable to the European Parliament (Zoppe et al. 2019).

\section{Addressing the Erosion of Democratic Legitimacy and Accountability of the EMU}

In order to correct the architectural omissions, which led to an erosion of democratic legitimacy and accountability both at EU and at national levels, it would thus be urgent to either abolish the Eurogroup altogether again given that the UK has left the European Union which had been one of the main reasons to establish it anyway. Otherwise, the best alternative would be to integrate it within the EU legal framework and thus correct the democratic deficit by making it fully accountable to the European Parliament. To avoid also a conflict of interest of president of the Eurogroup which is at the same time a full-time finance minister of a member-state, it would be better to introduce a full-time president of the Eurogroup, in whose nomination procedure the European Parliament would be involved. One possibility which has been proposed in the Commission' Reflection Paper on EMU was to merge this function with the Commissioner on economics and to make him Vice President of the European Commission. The European Parliament in turn could create a subcommittee on EMU and limit the voting rights to members of the European Parliament from EMU Member States in plenary.

Concerning the democratization of the financial assistance, be it within a European Monetary Fund (EMF) to be created, or by transforming the already existing European Stability Mechanism into an EMF, the important element is to give the European Parliament the right to co-decision on its architecture and to propose the changes necessary to take into account the lessons learnt from the assistance programmes of the last decade. It is clear that the policy recommendations within the financial assistance programmes cannot be a one-size-fits-all, but need to take into account the specific economic situation, crisis and circumstances of each country at a given time and respect democratic preferences of policies to achieve certain economic objectives. However, it would be extremely useful for the European Parliament to already define a certain framework and conditions and (human)rights which must be guaranteed.

Resuming the reforms undertaken or being discussed at EU level in the aftermath of the crisis, we can clearly identify that there is a persistent resistance to any measures of risk sharing both in the area of financial markets, but even more concerning 
fiscal policies. Yet, if we consider the most successful crisis management undertaken at EU level, we can clearly see that the ECB was the one institution which put on hold financial market speculation by demonstrating that they will do "whatever it takes" in a common monetary policy. Had there been a Eurozone budget or any other form of fiscal capacity in place, alone its existence would already have calmed down the eurocrisis, or it might even never have come about.

Changes of the treaties are a risky endeavour in the European Union. However, Fabbrini (2019) states that "the current EU constitutional framework already allows taking important steps towards the creation of a fiscal capacity, and Brexit -the decision of the United Kingdom (UK) to withdraw from the EU - actually opens a window of opportunity to this end. Nevertheless, as the in-depth analysis suggests in light of comparative insights, the proper design of a Eurozone budget is a precondition for its success: in particular, it is crucial that such a fiscal capacity be funded by real own resources, rather than state transfers, and subjected to mechanisms of democratic legitimation." Indeed, the UK departure represents a window of opportunity for treaty changes and a chance to move towards a more solidary and united European Union. Europe's resilience and role in the world actually depend on its capacity to grow together not only in the form of an internal market but truly towards a real Economic and Monetary Union, and on whether Europe can regain its influence by sharing sovereignty: "In a globalized world, sharing sovereignty is a way to regain sovereignty" (Draghi 2019).

Disclaimer The opinions expressed in this introduction/volume are the sole responsibility of the authors and do not necessarily represent the official position of the European Parliament or of any other EU institution.

\section{References}

Beblavý, M., Marconi, G., \& Maselli, I. (2015). A European unemployment benefits scheme: The rationale and the challenges ahead. CEPS Special Report, 19. https://www.ceps.eu/ceps-publications/european-unemployment-benefits-scheme-rationale-and-challenges-ahead/. Accessed 1 Mar 2020.

Delpla, J., \& Von Weizsaecker, J. (2011). Eurobonds: The blue bond concept and its implications. Bruegel Policy Contribution, Issue 2011/02 March 2011. https://bruegel.org/wp-content/ uploads/imported/publications/110322_pc_blue_bonds.pdf. Accessed 1 Mar 2020.

Dolls, M. (2018). An unemployment re-insurance scheme for the Eurozone? Stabilizing and redistribute effects. Bertelsmann Stiftung 2018. https://www.bertelsmann-stiftung.de/fileadmin/files/BSt/Publikationen/GrauePublikationen/EZ_Study_Re-Insurance_2018_ENG.pdf. Accessed 1 Mar 2020.

Draghi, M. (2019). Farewell speech, at the ECB, Frankfurt, 29 Oct 2019.

European Commission. (1977). The MacDougall report - Volume I. Study group on the role of public finance in European integration. http://ec.europa.eu/economy_finance/emu_history/ documentation/chapter8/19770401en73macdougallrepvol1.pdf. Accessed 1 Mar 2020.

European Commission. (2019). Commission communication on the European Green Deal, COM (2019) 640 final, 11.12.2019. https://ec.europa.eu/info/sites/info/files/european-green-dealcommunication_en.pdf. Accessed 1 Mar 2020. 
European Commission. (2020). European commission 2020 work programme: An ambitious roadmap for a union that strives for more. https://ec.europa.eu/commission/presscorner/detail/en/ IP_20_124. Accessed 1 Mar 2020.

European Fiscal Board. (2019). Assessment of the EU fiscal rules with a focus on the six-pack and two-pack legislation, August 2019. https://ec.europa.eu/info/publications/assessment-eu-fiscalrules-focus-six-and-two-pack-legislation_en. Accessed 1 Mar 2020.

European Parliament. (2011). Resolution of 6 July 2011 on the financial, economic and social crisis: Recommendations concerning the measures and initiatives to be taken (2010/2242(INI)). https://www.europarl.europa.eu/sides/getDoc.do?reference=P7-TA-2011-0331\&type=TA\&1 anguage $=E N \&$ redirect. Accessed 1 Mar 2020.

European Parliament. (2015). Resolution on the review of the economic governance framework: Stocktaking and challenges of 2015. https://www.europarl.europa.eu/doceo/document/ TA-8-2015-0238_EN.html. Accessed 1 Mar 2020.

European Parliament. (2017). Resolution on the budgetary capacity for the euro area in 2017. https://www.europarl.europa.eu/doceo/document/TA-8-2017-0050_EN.html. Accessed 1 Mar 2020.

European Commission. (2017). Reflection paper on the future of EU finances, 28 June 2017, https://ec.europa.eu/commission/sites/beta-political/files/reflection-paper-eu-finances_en.pdf

European Parliament. (2018). Draft report on the proposal for a regulation of the European Parliament and of the Council on the establishment o1f a European Investment Stabilisation Function (COM(2018)0387 - C8-0241/2018 - 2018/0212(COD)), Committee on Budgets and Committee on Economic and Monetary Affairs, Rapporteurs: Reimer Böge, Pervenche Berès, https://www.europarl.europa.eu/doceo/document/CJ16-PR-628556_EN.htm. 4 October 2018.

Fabbrini, F. (2019). A fiscal capacity for the Eurozone: Constitutional perspectives. In depth analysis. European Parliament, February 2019. https://www.europarl.europa.eu/RegData/etudes/ IDAN/2019/608862/IPOL_IDA(2019)608862_EN.pdf. Accessed 1 Mar 2020.

IMF Compilation Guide on Financial Soundness Indicators 2004, paragraphs 4.84-4.85, (https:// www.imf.org/external/np/sta/fsi/eng/2004/guide/index.htm)

Juncker, C. (2015). Completing Europe's economic and monetary union ("Five Presidents report"). Report by Jean-Claude Juncker, in close cooperation with Donald Tusk, J. Disselbloem, M. Draghi, \& M. Schultz. https://ec.europa.eu/commission/sites/beta-political/files/5-presidents-report_en.pdf. Accessed 1 Mar 2020.

Lenarčič, A., \& Korhonen, K. (2018). A case for a European rainy day fund. European stability mechanism. https://www.esm.europa.eu/sites/default/files/dp5.pdf. Accessed 1 Mar 2020.

Macron, E., \& Merkel, A. (2018). Meseberg declaration: Renewing Europe's promises of security and prosperity. 19 June 2018. https://archiv.bundesregierung.de/archiv-de/meta/startseite/ meseberg-declaration-1140806. Accessed 1 Mar 2020.

Van Rompuy H. (2012). Towards a genuine economic and monetary union/“Four Presidents report", Report by President of the European Council Herman Van Rompuy, EUCO 120/12, 26 June 2012. https://www.consilium.europa.eu/media/33785/131201.pdf

Zoppe, A., \& Dias, C. (2019). The European stability mechanism: main features, instruments and accountability. European Parliament. Economic Governance Support Unit. https://www. europarl.europa.eu/RegData/etudes/BRIE/2014/497755/IPOL-ECON_NT(2014)497755_ EN.pdf. Accessed 1 Mar 2020. 
Open Access This chapter is licensed under the terms of the Creative Commons Attribution 4.0 International License (http://creativecommons.org/licenses/by/4.0/), which permits use, sharing, adaptation, distribution and reproduction in any medium or format, as long as you give appropriate credit to the original author(s) and the source, provide a link to the Creative Commons license and indicate if changes were made.

The images or other third party material in this chapter are included in the chapter's Creative Commons license, unless indicated otherwise in a credit line to the material. If material is not included in the chapter's Creative Commons license and your intended use is not permitted by statutory regulation or exceeds the permitted use, you will need to obtain permission directly from the copyright holder. 